\title{
PERTANGGUNGJAWABAN PIDANA KORPORASI DALAM TINDAK PIDANA LINGKUNGAN HIDUP BERDASARKAN ASAS STRICT LIABILITY (STUDI KASUS PENCEMARAN LINGKUNGAN OLEH PT. RAYON UTAMA MAKMUR (RUM) KABUPATEN SUKOHARJO)
}

\author{
Henny Yunita Fitriani \\ Jaksa Pratama Kejaksaan Negeri Karanganyar \\ Dona Budi Kharisma \\ Dosen Hukum Perdata Fakultas Hukum Universitas Sebelas Maret \\ E-mail: donabudikharisma@staff.uns.ac.id
}

\begin{abstract}
Criminal act formulated in Environmental Protection Law Number 32 Year 2009 still contains an element of error (mens rea) as the main element that must be proven. In the case of environmental criminal acts committed by corporations, it is difficult to prove the causal relationship of the element of error with the criminal law act (actus reus). The strict liability doctrine can be applied as a basis for corporate criminal responsibility that commits environmental crimes by revising criminal provisions in environmental law (UUPPLH) by removing mens rea element, because the current UUPPLH only provides a basis for implementing strict liability in settling disputes through courts with a civil lawsuit mechanism. The expansion of the principle of strict liability in criminal law will more effectively impose corporate criminal responsibility, including in this paper the case of environmental pollution by PT. Rayon Utama Makmur (RUM) Sukoharjo.
\end{abstract}

Keywords: Crime Responsibility, PT. Rayon Utama Makmur (RUM) Sukoharjo, Strict Liability, UUPPLH.

\begin{abstract}
Abstrak
Perumusan tindak pidana dalam Undang-Undang Nomor 32 Tahun 2009 tentang Perlindungan dan Pengelolaan Lingkungan Hidup masih mengandung unsur kesalahan (mens rea) sebagai unsur pokok yang harus dibuktikan. Dalam kasus tindak pidana lingkungan yang dilakukan korporasi sulit untuk membuktikan hubungan kausal unsur kesalahan tersebut dengan perbuatan hukum pidana (actus reus). Doktrin strict liability dapat diterapkan sebagai dasar pertanggungjawaban pidana korporasi yang melakukan tindak pidana lingkungan hidup dengan cara merevisi ketentuan pidana dalam hukum lingkungan (UUPPLH) dengan menghapus unsur kesalahan, karena UUPPLH saat ini hanya memberikan dasar penerapan strict liability dalam penyelesaian sengketa melalui pengadilan dengan mekanisme gugatan perdata. Perluasan asas strict liability dalam ranah pidana akan membebankan pertanggungjawaban pidana korporasi secara lebih efektif, termasuk dalam makalah ini kasus pencemaran lingkungan oleh PT. Rayon Utama Makmur (RUM) Sukoharjo.
\end{abstract}

Kata Kunci: Pertanggungjawaban Pidana Korporasi, PT. Rayon Utama Makmur (RUM) Sukoharjo, Strict Liability, UUPPLH.

\section{A. Pendahuluan}

Pertanggungjawaban pidana atau criminal liability lahir dari timbulnya kerugian (harm) yang disebabkan oleh suatu tindak pidana (crime). Pertanggungjawaban pidana 
dikenakan dengan menempatkan pelaku sebagai subjek hukum pidana dalam ketentuan perundang-undangan. Hal ini bertujuan agar pelaku tindak pidana bertanggungjawab atas kesalahannya kepada korban karena telah melakukan suatu perbuatan hukum.

Subjek hukum pidana dalam tindak pidana lingkungan hidup tercantum dalam Pasal 1 angka 32 Undang-Undang Nomor 32 Tahun 2009 tentang Perlindungan dan Pengelolaan Lingkungan Hidup (selanjutnya disebut UUPPLH) yang menyatakan bahwa "Setiap orang adalah orang perseorangan atau badan usaha, baik yang berbadan hukum maupun yang tidak berbadan hukum.". Terminologi "badan usaha" dapat diartikan sebagai korporasi yang mana dengan ini merupakan bagian dari subjek tindak pidana lingkungan hidup dan dapat dikenakan pertanggungjawaban pidana sebagaimana yang dirumuskan dalam UUPPLH. ${ }^{1}$

Penempatan korporasi sebagai subjek hukum pidana tidak terlepas dari modernisasi sosial. Menurut Satjipto Rahardjo, semakin modern masyarakat, maka semakin kompleks pula sistem sosial, politik, dan ekonomi yang menyebabkan kebutuhan akan sistem pengendalian kehidupan formal. ${ }^{2}$ Tanda modernisasi dalam ekonomi salah satunya adalah dengan menempatkan korporasi sebagai subjek tindak pidana untuk menanggulangi dampak negatif yang ditimbulkan oleh adanya korprorasi. ${ }^{3}$

Pertanggungjawaban pidana korporasi sebagai subjek tindak pidana menimbulkan permasalahan manakala aparat penegak hukum masih berpaku pada asas kesalahan yaitu "tidak ada pidana tanpa adanya kesalahan" sedangkan korporasi bukanlah manusia yang memiliki sikap batin berupa kesalahan yang berbentuk kesengajaan maupun kealpaan. Harus disadari bahwa tindak pidana korporasi merupakan bagian dari white collar crime yang mana penentuan ada tidaknya tindak pidana tidak dapat dilihat dari sudut pandang biasa seperti tindak pidana pada umumnya. Penentuan unsur mens rea atau kesalahan korporasi tidaklah mudah karena terdapat hubungan yang begitu kompleks dalam tindak pidana terorganisasi. ${ }^{4}$

Penentuan kesalahan sangat erat kaitannya dengan proses pembuktian terutama dalam kasus tindak pidana lingkungan hidup. Pembuktian tindak pidana linkungan hidup yang sulit dan kompleks dapat diatasi dengan menerapkan doktrin strict liability. Menurut doktrin ini pertanggungjawaban pidana dibebankan kepada yang bersangkutan dengan tidak perlu dibuktikan adanya kesalahan (kesengajaan atau kelalaian) pada pelakunya. ${ }^{5} \mathrm{Jadi}$ pertanggungjawaban korporasi semata-mata berdasarkan bunyi undang-undang dengan tanpa memandang siapa yang melakukan kesalahan. Dalam strict liability, unsur kesalahan tersebut tidak perlu dibuktikan. ${ }^{6}$

Sebagai contoh kasus, penulis mengambil kasus pencemaran lingkungan yang dilakukan oleh PT. Rayon Utama Makmur (RUM) di Kabupaten Sukoharjo. PT. RUM berlokasi di Desa Plesan, Nguter, Sukoharjo yang memproduksi kapas sintetik (serat rayon) untuk kebutuhan garmen dan tekstil. Kegiatan produksi pabrik PT. RUM mulai menghasilkan

1 Masrudi Muchtar, Perlindungan dan Pengelolaan Lingkungan Hidup, (Jakarta: Prestasi Pustaka, 2015), hal. 131.

2 Satjipto Rahardjo, Hukum dan Masyarakat dan Pembangunan, (Bandung: Alumni, 1980), hal. 3-4.

3 Sarbini Sumawinata dalam Muladi Dwidja Priyatno, Pertanggungjawaban Pidana Korporasi, (Jakarta: Kencana Prenadamedia, 2012), hal. 44

4 Eddy O.S Hiariej, Prinsip-Prinsip Hukum Pidana, (Yogyakara: Cahaya Atma Pustaka, 2016), hal 202.

5 Ruslan Renggong, Hukum Pidana Lingkungan, (Jakarta: Kencana, 2018), hal. 108.

6 Eddy O.S Hiariej, Op.Cit, hal. 206 
limbah produksi berupa bau menyengat mulai dari Oktober 2017 dan meresahkan warga sekitar.

Hasil uji laboratorium Teknik Kimia Universitas Muhammadiyah Surakarta pada Januari-Februari 2018 menyatakan bahwa parameter TDS (Total Dissolved Solid) sample limbah cair PT. RUM berkisar 1.410-3.730 ppm, sehingga tidak memenuhi ambang baku mutu limbah cair. Sedangkan, untuk parameter COD (Chemical Oxygen Demand) sample limbah cair berkisar 24,48-420,24 mg/l, di mana ambang batas normal COD limbah cair lebih kecil dari 100 ppm maka dinyatakan tidak memenuhi ambang baku mutu limbah cair. Sedangkan untuk pengolahan limbah gas proses produksi, PT. RUM terindikasi belum secara maksimal mereduksi kandungan gas Hidrogen Sulfida (H2S). Dalam laporan juga disebutkan, sifat gas H2S memiliki densitas lebih tinggi (1,393 g/dm3) daripada densitas udara (1,293 g/dm3) sehingga memungkinkan gas H2S terhirup oleh masyarakat. Sementara, proses absorpsi di sekitar chimney (cerobong) belum maksimal sehingga masih banyak gas $\mathrm{H} 2 \mathrm{~S}$ yang terbuang ke udara. ${ }^{7}$

Pada 2018 PT. RUM akhirnya menghentikan operasionalnya berdasarkan Keputusan Bupati Sukoharjo Nomor: 660.1/207 Tahun 2018. Yang menjadi tolak ukur sanksi administratif tersebut adalah bahwa "PT. RUM tidak memasang Continous Emission Monitoring (CEM) pada cerobong Cimney sebagai upaya yang harus dilakukan dalam rangka pemantauan emisi; tidak secara optimal melakukan pengendalian emisi secara optimal sehingga menimbulkan dampak bau yang mengganggu masyarakat, sebagaimana diatur dalam Peraturan Pemerintah Nomor 41 Tahun 1999 Tentang Pengendalian Pencemaran Udara, dan; belum memenuhi kewajiban menyelesaikan pemasangan pipa pembuangan air limbah hasil pengolahan limbah dari Instalasi Pengolahan Air Limbah (IPAL) sampai dengan sungai Bengawan solo sebagaimana termuat dalam dokumen (AMDAL PT Rayon Utama Makmur)." 8 PT RUM diberikan waktu 18 bulan, guna menuntaskan persoalan mengenai bau gas hasil produksinya. ${ }^{9}$ PT. RUM juga diberikan sanksi oleh Menteri Kementerian Lingkungan Hidup dan Kehutanan melalui SK No. 4047/Menlhk-PHLHK/ PPSGA/GKM.016/2018 tentang Penerapan Sanksi Administratif Paksaan Pemerintah kepada PT. RUM, bahwa PT. RUM dianggap tidak menaati peraturan perundang-undangan lingkungan hidup.

Namun setelah bertahun-tahun pun masalah bau busuk dan pembuangan limbah cair oleh PT. RUM tidak kunjung usai. Pada bulan September 2019 Bupati Sukoharjo kembali memberikan sanksi administratif ke PT. RUM untuk menghentikan kegiatan produksi dan Oktober 2019 memberikan sanksi kedua berupa pengurangan volume produksi PT. RUM.

Hingga saat ini warga sekitar masih terganggu dengan bau busuk dan pencemaran limbah cair dari PT. RUM. Dampaknya, banyak warga yang mengalami sesak napas dan iritasi kulit. September 2020, pipa pembuangan limbah cair PT. RUM bocor dan mencemari Kali Gupit dan mulut sungai Bengawan Solo. Berdasarkan hasil uji Laboratorium Teknik Kimia Universitas Muhammadiyah Surakarta, kadar sulfida dan tingkat kebutuhan oksigen kimiawi (COD) melebihi ambang batas baku mutu. Kandungan sulfida yang tinggi menyebabkan

7 Fauziah Ratih Widyastuti, "Penyelesaian Sengketa Lingkungan Hidup (Studi Kasus PT. RUM di Kabupaten Sukoharjo", Naskah Publikasi Universitas Muhammadiyah Surakarta, (2018), hal. 6-7.

8 Ibid.

9 Edi Suwiknyo, "Menelusuri Jejak Limbah Rayon Utama Makmur", Bisnis.com 11 Agustus 2020, diakses di https:// ekonomi.bisnis.com/read/20200811/257/1277783/menelusuri-jejak-limbah-rayon-utama-makmur- pada 20 Oktober 2020 
gatal dan air berbau menyengat, sementara kadar COD yang tinggi bisa membuat ikanikan di sungai itu mati. ${ }^{10}$ Hingga saat ini PT. RUM masih berusaha menangani limbah produksinya dengan mendatangkan mesin tambahan instalasi pengolahan limbah yang ketiganya akan selesai pada tahun $2021 .{ }^{11}$

Berdasarkan uraian di atas, penulis mempersempit bahasan dari makalah ini ke dalam dua rumusan masalah berikut: Bagaimana pertanggungjawaban pidana korporasi dalam Tindak Pidana Lingkungan Hidup berdasarkan asas strict liability? Serta Bagaimana analisis terkait penerapan asas strict liability dalam pertanggungjawaban pidana korporasi kasus pencemaran yang dilakukan oleh PT. Rayon Utama Makmur?

Jenis penelitian dalam makalah ini adalah penelitian hukum normatif atau doctrinal research. Penulis menggunakan dua pendekatan dalam makalah ini, yaitu pendekatan perundang-undangan dan pendekatan konseptual. Pendekatan perundang-undangan (Statute Approach) dilakukan dengan cara menelaah semua undang-undang dan regulasi yang relevan dengan isu yang dihadapi ${ }^{12}$. Pendekatan konseptual (Conceptual Approach) digunakan penulis untuk mengkaji mengenai penerapan asas strict liability dalam pertanggungjawaban pidana dan pemidanaan korporasi dalam Tindak Pidana Lingkungan Hidup yang disertai contoh kasus pencemaran lingkungan yang dilakukan oleh PT. RUM Sukoharjo.

\section{B. Pembahasan}

\section{Pertanggungjawaban Pidana Korporasi Berdasarkan Asas Strict Liability dalam Tindak Pidana Lingkungan Hidup}

Kejahatan korporasi merupakan kejahatan white collar crime. ${ }^{13}$ Untuk itu kepada korporasi harus dapat dibebankan pertanggungjawaban pidana atas perbuatan hukumnya termasuk dalam melakukan tindak pidana lingkungan hidup. Menurut $\mathrm{Lu}$ Sudirman dan Feronica, ada tiga parameter yang dapat digunakan untuk memidana korporasi. Pertama, undang-undang telah mengatur dengan tegas bahwa subjek tindak pidananya termasuk korporasi. Parameter ini sangat penting terkait asas legalitas. Kedua, korporasi dapat disertakan sebagai tersangka jika penyidik telah menentukan bahwa tersangka personalnya adalah pejabat yang dianggap mewakili korporasi dan menjadi directing mind and will dari korporasi. Ketiga korporasi tidak dapat dikenakan pertanggungjawaban pidana apabila directing mind and will korporasi melakukan tindak pidana terhadap korporasi mereka sendiri dan korporasi yang bersangkutan sudah melakukan penuntutan terhadap tindakan tersebut. Parameter ini menegaskan bahwa suatu perbuatan disebut sebagai tindak pidana korporasi apabila tindakan tersebut memberikan manfaat dan keuntungan bagi korporasi. ${ }^{14}$

10 Zakki Amali, “Bau Busuk Limbah Pabrik Pencemar Bengawan Solo”, Tirto.id 18 September 2020, diakses di https://tirto. id/bau-busuk-limbah-pabrik-pencemar-bengawan-solo-f4GM pada 20 Oktober 2020

11 Indah Septiyaning Wardani, "Sabar...! Bau Limbah PT. RUM Sukoharjo Hilang 100 Persen Tahun Depan”, Solopos. com 23 Januari 2020, diakses di https://www.solopos.com/sabar-bau-limbah-pt-rum-sukoharjo-hilang-100-persen-tahundepan-1043359 pada 20 Oktober 2020

12 Peter Mahmud Marzuki, Penelitian Hukum Edisi Revisi, (Jakarta: Kencana Prenada Media Group, 2014), hal. 133

13 Mardjono Reksodipoetro, "Tindak Pidana Korporasi dan Pertanggungjawabannya: Perubahan Wajah Pelaku Kejahatan di Indonesia", Makalah Universitas Gadjah Mada, (2014), hal. 8.

14 Lu Sudirman dan Feronica, "Pembuktian Pertanggungjawaban Pidana Lingkungan dan Korupsi Korporasi di Indonesia da 
Menurut Roeslan Saleh, dalam pertanggungjawaban pidana korporasi asas geen straf zonder schuld atau unsur kesalahan tidak mutlak berlaku. Dalam pertanggungjawaban korporasi, tidak perlu selalu diperhatikan kesalahan si pembuat namun cukup dengan melihat fakta bahwa kerugian yang ditimbulkan oleh perbuatan pidana korporasi sangat besar baik secara fisik, ekonomi, dan social cost yang mengorbankan masyarakat dan negara. ${ }^{15}$

Ada beberapa doktrin yang dapat digunakan untuk menghukum korporasi dan menilai pertanggungjawaban korporasi, salah satunya doktrin strict liability atau pertanggungjawaban ketat menurut undang-undang. Konsep strict liability merupakan pengecualian dari asas "tidak ada pidana tanpa kesalahan" dengan begitu asas ini tidak berlaku bagi semua tindak pidana tetapi hanya untuk tindak pidana tertentu dalam undang-undang. Untuk tindak pidana tertentu tersebut, pembuat tindak pidananya telah dapat dipidana hanya karena telah dipenuhinya unsur-unsur tindak pidana oleh perbuatannya. ${ }^{16}$

Beberapa literatur menyebutkan asas strict liability sama dengan absolute liability. Namun sebenarnya ada beberapa perbedaan yang mencolok antara kedua asas tersebut. Absolute liability disebut juga dengan liability based on fault sedangkan strict liability masuk ke dalam liability without fault. Dalam konsep strict liability kesalahan tidak semata sebagai faktor yang menentukan tanggungjawab, namun ada pengecualiannya yang memungkinkan dapat membebaskan tanggungjawab, seperti keadaan darurat. Sedangkan dalam absolute liability tanggungjawab menjadi mutlak (absolute) tanpa kesalahan dan tidak ada pengecualiannya. ${ }^{17}$ Jadi permasalahannya terletak dalam sejauh mana prinsip kesalahan dan pertanggungjawaban pidana itu diperluas dengan tetap memperhatikan keseimbangan kepentingan individu dan kepentingan masyarakat luas. ${ }^{18}$

Untuk itu Barda Nawawi Arief dalam bukunya menyatakan bahwa penerapan asas strict liability ini harus ditujukan pada delik-delik tertentu yaitu delik yang diatur dalam undang-undang dan menyangkut kesejahteraan umum (public welfare). ${ }^{19}$ Kejahatan yang membahayakan masyarakat itu tidak harus merupakan kejahatan yang serius (real crime) namun juga termasuk regulatory offences seperti pencemaran lingkungan. ${ }^{20}$

Dari uraian tersebut terdapat beberapa patokan dalam menerapkan asas strict liability ke dalam delik pidana, yaitu: a. asas strict liability hanya dapat diterapkan dalam delik tertentu terutama yang mengancam kesejahteraan masyarakat, $b$. perbuatan tersebut benar-benar melawan hukum, c. perbuatan tersebut dilarang oleh undang-undang karena dikategorikan sebagai perbuatan yang mengancam kesehatan,

Singapura", Mimbar Hukum Vol. 23 Nomor 2 Juni, (2011), hal 301-302

15 Eddy O.S Hiariej, Op. Cit, hal 204-205

16 Subaidah Ratna Juita, Dewi Tuti Muryati, dan Ani Triwati, “Asas Strict Liability dalam Pertanggungjawaban Pidana Pada Korporasi Pelaku Tindak Pidana Linkungan Hidup”, Jurnal Nasional 10 Desember 2014, (2014), hal. 8

17 Bayu Haritia dan Hartiwiningsih, "Penerapan Asas Strict Liability Dalam Tindak Pidana Kebakaran Hutan dan Lahan yang Dilakukan Korporasi (Studi Putusan Nomor 186/Pid.Sus/2015/PT PBR)”, Jurnal Recidive Vol. 8, (2019), hal. 115

18 Subaidah Ratna Juita, Dewi Tuti Muryati, dan Ani Triwati, Op. Cit, hal. 10 
keselamatan, dan moral publik, dan d. perbuatan itu dilakukan dengan cara melakukan pencegahan yang sangat wajar. ${ }^{21}$

Penerapan asas strict liability untuk meminta pertanggungjawaban pidana kepada korporasi yang melakukan tindak pidana lingkungan tidak pernah diterapkan dalam hukum Indonesia. Pasal 88 Undang-Undang Nomor 32 Tahun 2009 tentang Perlindungan dan Pengelolaan Lingkungan Hidup sebenarnya sudah dapat dikatakan mengandung asas strict liability "Setiap orang yang tindakannya, usahanya, dan/atau kegiatannya menggunakan B3, menghasilkan dan/atau mengelola limbah B3, dan/atau yang menimbulkan ancaman serius terhadap lingkungan hidup bertanggung jawab mutlak atas kerugian yang terjadi tanpa perlu pembuktian unsur kesalahan."22

Bila dilihat dari unsur-unsur yang ada dalam pasal tersebut terutama "tanpa perlu pembuktian unsur kesalahan" mengandung asas strict liability. Namun jika melihat dalam penjelasan Pasal 88 UUPPLH yang menyatakan bahwa "yang dimaksud dengan "bertanggung jawab mutlak" atau strict liability adalah unsur kesalahan tidak perlu dibuktikan oleh pihak penggugat sebagai dasar pembayaran ganti rugi. Ketentuan ayat ini merupakan lex specialis dalam gugatan tentang perbuatan melanggar hukum pada umumnya", maka sebenarnya asas ini hanya dapat diterapkan dalam hal penyelesaian sengketa lingkungan diselesaikan melalui pengadilan melalui gugatan keperdataann. ${ }^{23}$ Pasal 88 UUPPLH juga ditempatkan dalam bagian Penyelesaian Sengketa Lingkungan Hidup Melalui Pengadilan dalam UUPPPLH. Oleh karena itu pasal ini tidak bisa digunakan dalam hal penyelesaian sengketa melalui jalur pidana.

Ini menyebabkan pertanggungjawaban pidana oleh korporasi mengalami impunity, yaitu kekebalan hukum atas berbagai kejahatan yang mereka lakukan sehingga meskipun mereka melakukan kejahatan tidak ada usaha untuk memproses korporasi dengan hukum pidana secara maksimal. ${ }^{24}$ Padahal tindak pidana lingkungan yang dilakukan korporasi cenderung sulit pembuktiannya jika harus membuktikan pula unsur kesalahan baik kesengajaan dan kealpaan. Penerapan asas strict liability untuk meminta pertanggungjawaban pidana korporasi akan sangat membantu aparat penegak hukum dalam proses penuntutan dan pembuktian dalam persidangan.

Oleh karena itu, perlu diterapkannya asas pertangungjawaban mutlak (strict liability) bukan hanya dalam proses penegakan hukum secara keperdataan tetapi juga perlu diterapkan dalam proses peradilan pidana. ${ }^{25} \mathrm{Hal}$ ini menurut penulis dapat dilakukan dengan mereformulasi kembali ketentuan pidana dalam UUPPLH berdasarkan asas strict liability yang menghapuskan unsur kesalahan dalam rumusan pidananya.

\section{Analisis Penerapan Strict Liability dalam Kasus Pencemaran PT. RUM}

Untuk dapat dihukumnya korporasi atau memidanakan korporasi, salah satu unsur penting menurut Lu Sudirman dan Feronica adalah terkait diakuinya korporasi sebagai

21 Ibid.

22 Pasal 88 Undang-Undang Nomor 32 Tahun 2009 tentang Perlindungan dan Pengelolaan Lingkungan Hidup

23 Penjelasan Pasal 88 Undang-Undang Nomor 32 Tahun 2009 tentang Perlindungan dan Pengelolaan Lingkungan Hidup

24 Ridho Kurniawan dan Siti Nurul Intan Sari D, "Pertanggungjawaban Pidana Korporasi Berdasarkan Asas Strict Liability (Studi Pembaharuan Hukum Pidana Lingkungan Hidup)”, Jurnal Yuridis Vol.1, No. 2, (2014), hal. 161

25 Ibid. 
subjek hukum dalam peraturan perundang-undangan. ${ }^{26}$ Pasal 1 angka 32 UUPPLH sudah mengakui korporasi sebagai subjek hukum yaitu "Setiap orang adalah orang perseorangan atau badan usaha, baik yang berbadan hukum maupun yang tidak berbadan hukum".

Pasal 116 UUPPLH juga menyatakan bahwa "Apabila tindak pidana lingkungan hidup dilakukan oleh, untuk, atau atas nama badan usaha, tuntutan pidana dan sanksi pidana dijatuhkan kepada: a. badan usaha; dan/atau b. orang yang memberi perintah untuk melakukan tindak pidana tersebut atau orang yang bertindak sebagai pemimpin kegiatan dalam tindak pidana tersebut." Ini berarti korporasi dapat dibebankan pertanggungjawaban pidana jika melakukan perbuatan-perbuatan hukum yang dilarang dalam UUPPLH, tidak termasuk PT. Rayon Utama Makmur jika terbukti secara sah dan meyakinkan melakukan pencemaran lingkungan.

Sebagaimana telah dijelaskan sebelumnya, menurut hasil uji laboratorium Teknik Kimia Universitas Muhamadiyah Surakarta yang dinisiasi secara mandiri oleh masyarakat terdampak, kegiatan produksi PT. RUM telah menghasilkan zat yang berbahaya, baik berupa gas dan cairan. Kadar sulfida dan tingkat kebutuhan oksigen kimiawi (COD) melebihi ambang batas baku mutu. Kandungan sulfida yang tinggi menyebabkan gatal dan air berbau menyengat, sementara kadar COD yang tinggi bisa membuat ikan-ikan di sungai itu mati. ${ }^{27}$

Fakta bahwaKementerianLingkungan Hidupdan Kehutananjuga sudahmemberikan sanksi administratif kepada PT. RUM melalui SK No. 4047/Menlhk-PHLHK/PPSGA/ GKM.016/2018 tentang Penerapan Sanksi Administratif Paksaan Pemerintah kepada PT. RUM semakin menguatkan bukti bahwa PT. RUM telah melakukan pencemaran lingkungan dan dapat dijerat sanksi pidana. Belum lagi kerugian yang ditimbulkan juga sangat meresahkan masyarakat luas dan dalam waktu yang lama.

Parameter lain dalam memidanakan korporasi yaitu bahwa tindak pidana lingkungan yang dilakukan menghasilkan keuntungan bagi korporasi. Dalam kasus PT. RUM, setelah terus menerus mendapat desakan baik dari pemerintah dan masyarakat, akhirnya PT. RUM bersedia untuk mendatangkan mesin pengelolaan limbah untuk kegiatan produksinya yang baru akan selesai tahun 2021. Mesin tersebut memakan biaya hingga Rp 700 Miliar. ${ }^{28}$ Menurut penulis hal ini membuktikan bahwa jika PT. RUM secara benar mengelola limbah kegiatan produksinya, PT. RUM membutuhkan dana sekiranya sesuai angka tersebut, dan fakta bahwa PT. RUM tidak melakukannya sejak awal dan malah mengorbankan lingkungan dan masyarakat dapat dikatakan sebagai keuntungan korporasi karena mengurangi modal yang dikeluarkan untuk mengelola limbahnya.

Namun untuk meminta pertanggungjawaban pidana terhadap PT. RUM sebagai pelaku pencemaran, akan sulit dalam proses penuntutan dan pembuktiannya manakala perumusan tindak pidana dalam ketentuan pidana UUPPLH masih memasukan unsur

26 Lu Sudirman dan Feronica, Loc. Cit.

27 Zakki Amali, Tirto.id, Loc. Cit.

28 Indah Septiyaning Wardani, Solopos.com, Loc. Cit. 
kesengajaan dan kelalaian. ${ }^{29}$ Di lain sisi, Pasal 88 UUPPLH yang menganut asas strict liability tidak dapat diterapkan dalam pertanggungjawaban pidana korporasi karena hanya dapat digunakan dalam penyelesaian sengketa melalui gugatan perdata.

Jika dilihat dari penerapan strict liability sebagai bentuk pertanggungjawaban pidana berdasarkan asas kesalahan diadopsi dari konsep kesalahan normatif. Teori kesalahan normatif menyebabkan kesalahan tidak mutlak harus dilihat sebagai kondisi kejiwaan manusia yang ditandai dengan kesengajaan atau kealpaan. Dengan demikian memungkinkan kesalahan terdapat bukan hanya pada subjek hukum manusia tetapi juga pada korporasi karena akan sangat sulit untuk menentukan adanya kesalahan pada korporasi jika kesalahan semata-mata dilihat sebagai masalah psikologis. ${ }^{30}$

Asas strict liability diartikan sebagai kewajiban mutlak dengan ciri-ciri utama tidak perlu adanya (pembuktian) kesalahan lebih jauh. Seperti pendapat Barda Nawawi Arief, kesalahannya (mens rea) tetap ada tetapi tidak harus dibuktikan. Terdakwa dapat dinyatakan bersalah hanya dengan membuktikan telah dilakukannya tindak pidana (actus reus) tanpa harus melihat motif dilakukannya tindak pidana tersebut. Untuk itu perlunya suatu reformulasi ketentuan pidana dalam tindak pidana lingkungan hidup dengan menghapuskan unsur kesengajaan dan kealpaan dalam perumusan tindak pidananya, dalam hal ini UUPPLH.

\section{Penutup}

Penerapan asas strict liability dalam pertanggungjawaban pidana korporasi sebagai pelaku tindak pidana lingkungan hidup untuk saat ini belum bisa dilakukan lantaran kebijakan dan instrumen hukum yang tidak mendukung. Asas strict liability dalam tindak pidana lingkungan hidup sebenarnya sudah tercantum dalam Pasal 88 Undang-Undang Nomor 32 Tahun 2009 tentang Perlindungan dan Pengelolaan Lingkungan Hidup. Namun dilihat dari penjelasan UUPPLH, penerapan pasal tersebut hanya berlaku dalam penyelesaian sengketa melalui pengadilan dengan mekanisme gugatan keperdataan, spesifiknya mengenai ganti kerugian. Penerapan asas strict liability dalam pertanggungjawaban pidana korporasi yang melakukan tindak pidana lingkungan akan sangat membantu dalam proses pembuktian dan penegakan hukum, karena sifat tindak pidana lingkungan korporasi yang unsur kesengajaan maupun kealpaannya sulit dibuktikan karena berkaitan dengan sikap batin atau psikologis.

Kasus pencemaran yang dilakukan PT. Rayon Utama Makmur (RUM) di Kabupaten Sukoharjo tidak dapat diselesaikan secara pidana jika melihat pada peraturan perundangundangan saat ini. Dalam hal ini asas strict liability hanya dapat diterapkan jika penyelesaian sengketa dilakukan dengan mekanisme gugatan perdata bukan pidana. Hal ini dapat diatasi jika Undang-Undang Nomor 32 Tahun 2009 tentang Perlindungan dan Pengelolaan Lingkungan Hidup terutama bagian Ketentuan Pidana UUPPLH direvisi dengan menerapkan asas strict liability dalam perumusan tindak pidananya. Ini juga bertujuan untuk mencegah pertanggungjawaban pidana oleh korporasi mengalami impunity.

29 Lihat Bab tentang Ketentuan Pidana Undang-Undang Nomor 32 Tahun 2009 tentang Perlindungan dan Pengelolaan Lingkungan Hidup.

30 Ridho Kurniawan dan Siti Nurul Intan Sari D, Op. Cit, hal. 162 


\section{DAFTAR PUSTAKA}

\section{Buku}

Arief, Barda Nawawi. 1990. Perbandingan Hukum Pidana. Cetakan Pertama. Jakarta: CV. Rajawali.

Hiariej, Eddy O.S. 2016. Prinsip-Prinsip Hukum Pidana. Yogyakara: Cahaya Atma Pustaka.

Marzuki, Peter Mahmud. 2014. Penelitian Hukum Edisi Revisi. Jakarta: Kencana Prenada Media Group.

Muchtar, Masrudi. 2015. Perlindungan dan Pengelolaan Lingkungan Hidup. Jakarta: Prestasi Pustaka

Priyatno, Muladi Dwidja. 2012. Pertanggungjawaban Pidana Korporasi. Jakarta: Kencana Prenadamedia.

Rahardjo, Satjipto. 1980. Hukum dan Masyarakat dan Pembangunan. Bandung: Alumni.

Renggong, Ruslan. 2018. Hukum Pidana Lingkungan. Jakarta: Kencana.

\section{Artikel dan Jurnal}

Haritia, Bayu dan Hartiwiningsih. 2019. "Penerapan Asas Strict Liability Dalam Tindak Pidana Kebakaran Hutan dan Lahan yang Dilakukan Korporasi (Studi Putusan Nomor 186/Pid. Sus/2015/PT PBR)". Jurnal Recidive Vol. 8.

Juita, Subaidah Ratna, Dewi Tuti Muryati, dan Ani Triwati. 2014. "Asas Strict Liability dalam Pertanggungjawaban Pidana Pada Korporasi Pelaku Tindak Pidana Linkungan Hidup”, Jurnal Nasional 10 Desember 2014.

Kurniawan, Ridho dan Siti Nurul Intan Sari D. 2014. "Pertanggungjawaban Pidana Korporasi Berdasarkan Asas Strict Liability (Studi Pembaharuan Hukum Pidana Lingkungan Hidup)". Jurnal Yuridis Vol.1, No. 2.

Reksodipoetro, Mardjono. 2014. "Tindak Pidana Korporasi dan Pertanggungjawabannya: Perubahan Wajah Pelaku Kejahatan di Indonesia". Makalah Universitas Gadjah Mada

Sudirman, Lu dan Feronica. 2011. "Pembuktian Pertanggungjawaban Pidana Lingkungan dan Korupsi Korporasi di Indonesia da Singapura”. Mimbar Hukum Vol. 23 Nomor 2 Juni.

Widyastuti, Fauziah Ratih. 2018. "Penyelesaian Sengketa Lingkungan Hidup (Studi Kasus PT. RUM di Kabupaten Sukoharjo". Naskah Publikasi Universitas Muhammadiyah Surakarta.

\section{Peraturan Perundang-Undangan}

Undang-Undang Nomor 32 Tahun 2009 tentang Perlindungan dan Pengelolaan Lingkungan Hidup 


\section{Pustaka Maya}

Amali, Zakki. Tirto.id. "Bau Busuk Limbah Pabrik Pencemar Bengawan Solo". 18 September 2020, diakses di https://tirto.id/bau-busuk-limbah-pabrik-pencemar-bengawan-solof4GM pada 20 Oktober 2020

Suwiknyo, Edi. Bisnis.com. "Menelusuri Jejak Limbah Rayon Utama Makmur”. 11 Agustus 2020, diakses di

https://ekonomi.bisnis.com/read/20200811/257/1277783/menelusuri-jejak-limbah-rayonutama-makmur- pada 20 Oktober 2020.

Wardani, Indah Septiyaning. Solopos.com. “Sabar...! Bau Limbah PT. RUM Sukoharjo Hilang 100 Persen Tahun Depan”. 23 Januari 2020, diakses di https://www.solopos.com/sabarbau-limbah-pt-rum-sukoharjo-hilang-100-persen-tahun-depan-1043359 pada 20 Oktober 2020 